\title{
INTERACTION OF AUTHORITIES AND MEDIA IN THE FIELD OF COUNTERING DISINFORMATION IN UKRAINE
}

\section{Silenko A. A., Kormych A. I.}

\section{INTRODUCTION}

The relevance of the article is due to the fact that in a modern democratic state, the government needs the support of citizens as potential voters, delegating the power of authority of a party to their choice. The collective nature of most of the goals realized in politics involves the use of special means by transmitting the desired information that can provide a single direction for the actions of a large number of people, i.e. mobilize them for mass action. It is mass media that turn out to be the only such means, given their function of forming an information analogue of society, and the consequence of this situation is the special role of the media in the modern political process and their huge impact on political life. Much of what is happening in the world today is happening with an eye on the mass media that record and broadcast it. In this new situation, the media act as agents of authority, seizing from the public sphere the possibility of rational and critical discussions.

In general, the role of the media is determined by their ability to shape the media agenda in political discourse and influence decision-making mechanisms. However, as practice shows, the media do not always seek to reflect the interests of society and give people objective information. Mass media actively disseminate political information, stories and comments on them. And it is quite difficult for an average person who has little knowledge of political issues to navigate and understand which comments are professional and which are manipulative.

For example, S. Bennett identifies four varieties of distortion of news: personalization, dramatization, fragmentation and normalization. Personalization of news involves focusing on specific personalities during a story about processes, events or phenomena. Dramatization occurs when news material is selected based on its high dramatic or entertaining significance, and not because of its importance to society. Fragmentation involves the transmission of news in separate concise bulletins (news 
releases, special programs or headings), their fragmentation. Normalization presupposes the presentation of news as a problem that can be solved in accordance with the norms existing in society ${ }^{1}$.

The facts of manipulation by the media, their use for special information operations, bias and prejudice in reporting on social and political events lead to a drop in public confidence in the media, in this connection we can recall the famous remark by N. Luhmann, with which he begins his the book "The reality of the media": "Everything that we know about our society and even the world in which we live, we know through the media ... And, on the contrary, we know we have so much about the media that we are unable to trust them as a source of information" ${ }^{2}$.

This determines the need of the state and society to influence their information activities, to set their own priorities through the media in the nomination and interpretation of political problems. In this regard, the study of contemporary trends and prospects for the development of media policy in a democratic society becomes relevant for political science.

The purpose of this article is to consider the process of interaction between the government and the media in the field of countering disinformation in Ukraine.

The term "misinformation" was introduced by the high command of the German army during the First World War to refer to that part of the field tactics of working with the enemy, the purpose of which was to mislead him. This tactic implied a direct deception of the enemy, the use of lies, slander, half-truths, sometimes hiding not only the true content of phenomena and facts, but also their very existence.

According to E. Samoshkin, "Disinformation ... is a deliberate act of human activity, an attempt to create a false impression and, accordingly, push an object to desired actions or inaction. A characteristic feature of the "desa" is that it is actively used in wartime, it does not matter if this war is "hot" or "cold".

\footnotetext{
${ }^{1}$ Брайант, Дж. (2004). Основы медиа-воздействия. М., 2004, 432 с. С. 157.

2 Luhmann, N. (1996). Die Realitat der Massenmedien. Opladen: Westdeutscher Verlag, 223 p. P. 9.

${ }^{3}$ Самошкин, Е.А. (2017) Институты борьбы с дезинформацией и мисинформацией в СМИ. Вестн. Моск. ун-та. Сер.10. Журналистика. № 6. С. 178.
} 
The Oxford Living Dictionary defines disinformation as "misleading information that is propaganda created by government organizations against opponents or the media" 4 .

The problems of information communication are revealed in the scientific works of M. Weber, K. Manheim, T. Parsons, P. Sorokin, D. Bell, N. Wiener, M. Castells, E. Toffler and many others. The works of Ukrainian researchers G. Pocheptsov, V. Volyansky, V. Nedbay, A. Dubas and others are devoted to various aspects of political communication.

\section{Ukraine in international ratings of freedom of speech and the media}

In Ukraine, media-democratic processes developed in a slightly different scenario, unlike the West. And although the development of power relations in Ukraine now also largely depends on communication, and the positioning of actors in the political space and their power capabilities - on the density of communications and the use of marketing technologies for organizing political discourse, the sources, social content and consequences of these transformations in Ukraine have a distinct specifics.

The most important prerequisite for strengthening the political role of the media in Ukrainian conditions was a poorly structured mechanism for representing civil interests, which after the destruction of the party-state apparatus of the Communists was able to transmit the social needs of only the ruling class. The emerging political market began to take on a media profile, since in the second third of the 1990s, large capital, which was gradually turning into the main political player, began to consistently buy up the media in order to strengthen its power position. The concentration of ownership in this area led to the political dominance of media empires.

The desire for European integration confirms the inviolability of Ukraine's choice of democracy, which is inextricably linked to human rights. Human rights as the most important value of democracy are enshrined in the Universal Declaration of Human Rights, Art. 19 of which states that "Everyone has the right to freedom of opinion and expression; this right includes freedom to hold one's convictions freely and freedom to seek, receive and disseminate information and ideas by any means and regardless of state borders”, and Art. 19 and 20 of the International Covenant on Civil and Political Rights of December 16, 1966.

${ }^{4}$ Oxford living dictionaries. Definition of disinformation in English. Available at: https://en.oxforddictionaries.com/definition/disinformation. 
Under the conditions of totalitarianism and authoritarianism, the mass media are not a leading force in the information space; their activity is aimed at serving the information needs of the authorities. As you know, a totalitarian political regime seeks to maximize its influence and minimize the autonomy of the individual. Therefore, technological progress in the field of telecommunications is used so that everyone receives messages and the ruling regime, but so that no one can become an independent sender of information. Traditional broadcast media (radio, television) have always served the totalitarian regime as a powerful political weapon aimed at cultivating authoritarian and uniform forms of thinking. As the famous American political scientist $\mathrm{B}$. Cohen said, "the media may not be very successful in explaining to people what to think, but they are incredibly successful in explaining to them what to think about." And you can add what not to think about ${ }^{5}$.

In conditions of democracy, the state is perceived as an institution whose function is to protect the rights and freedoms of the individual, national interests. The democratic political regime is characterized by free competition of ideas on the socio-political market, the participants of which are many generators and many recipients of information. Technological progress in this direction should correlate with the expansion of the population's access to interactive communications. A democratic state is forced to take public opinion into account, which is made public by the free media.

According to a study by the Kiev International Institute of Sociology, of all the media, Ukrainians most of all trust Ukrainian television - $40 \%$ of respondents, Ukrainian Internet media $-14 \%$, social networks $-12 \%{ }^{6}$.

According to the Reporters Without Borders International Human Rights Organization, which measures the annual index of media freedom in the world, Ukraine ranked 102nd in the ranking published on April 18, as of 2019, which is one notch lower than in $2018{ }^{7}$.

Also, the fact that the International Federation of Journalists included Ukraine among the 5 countries with a high level of danger for the work of

5 Золотникова М.С. Роль средств массовой информации в формировании идеологиии культурных ценностей общества Available at: http://elar.rsvpu.ru/bitstream/ 123456789/6882/1/it_mho_2008_3_006.pdf.

${ }^{6}$ По данным социологического опроса КМИС, центральным телеканалам доверяют 40\% опрошенных украинцев Available at: https://news.liga.net/society/news/komu-iz-smibolshe-vsego-doveryayut-ukraintsy---opros.

${ }^{7}$ Украина опустилась в рейтинге свободы слова Available at: https://tsn.ua/ru/ ukrayina/ukraina-opustilas-v-reytinge-svobody-slova-1331460.html. Available from https://tsn.ua/ru/ukrayina/ukraina-opustilas-v-reytinge-svobody-slova-1331460.html. 
journalists does not add credibility to us (the International Federation of Journalists included Ukraine amoAs they say, everything is known by comparison, therefore, we will analyze the degree of freedom of the information space of Ukraine under three presidents $-V$. Yanukovych, P. Poroshenko, V. Zelensky.

\section{Freedom of speech and information under the Presidents of Ukraine Viktor Yanukovych and Petro Poroshenko}

With the coming to power of V. Yanukovych, the information sphere was almost completely under the control of the authorities. Attacks on journalists were not investigated, the activities of government officials and deputies rarely became the subject of criticism, the opposition was increasingly less likely to be seen and heard in the media.

The idea of censorship of social networks appeared in Ukraine under V. Yanukovych in 2010, when the Ministry of Internal Affairs of Ukraine announced the start of the fight against illegal materials on the Internet. It was planned to check all VKontakte pages for pornography. The subject of the search was photographs and videos of child pornography, scenes of murder and violence.

However, experts expressed the view that the intentions of the Ministry of Internal Affairs of Ukraine were initially aimed at establishing full control over the network. "The fight against porn is an excuse for full control of network users. If they get control over their accounts, they will also receive general access to the network, which they can use as they wish, even for political purposes," suggested the head of Proloject as part of Advanter Group Anton Beletsky. At that time, about $80 \%$ of Internet users were members of social networks. Of these, $70 \%$ were VKontakte users. Therefore, having gained control over one site, the Ministry of Internal Affairs would automatically have gained control of almost all Ukrainian Internet users ${ }^{8}$.

In 2011, Freedom House, a human rights organization, noted that the state of press freedom in Ukraine has worsened and is rated as "partially free." This is a negative trend in Ukraine since the country had long been among the best press freedom in the region for a long time. But after President Viktor Yanukovych came to power last year, this freedom decreased.

\footnotetext{
${ }^{8}$ Милиция перечитает страницы пользователей "ВКонтакте" Available at: http://podrobnosti.ua/internet/2010/07/07/698868.html.
} 
Human rights activists, among other things, recalled that radio stations and television companies that criticized the authorities had lost their frequencies. Also in Ukraine, illegal harassment and intimidation of journalists has increased, leading to a deepening of self-censorship ${ }^{9}$.

However, in 2011 media experts, including Valery Ivanov (Academy of Ukrainian Press), Victoria Syumar (Institute of Mass Media), Natalya Likhacheva (GO Telekritika), Natalya Kostenko (Institute of Sociology of the National Academy of Sciences of Ukraine), noted that the situation in 2011 was The media space can hardly be called analogous to the strict regulation of the information environment by the authorities during the time of Kuchma. They evaluated the media climate under Yanukovych as milder than during the Kuchmism era. Their explanation is that "Firstly, the government does not have a sufficiently large professional propaganda machine capable of developing content and imposing its own discourse exclusively. Secondly, the print media remains a zone of relative freedom. Thirdly, the Internet is gaining enough weight. -channels through which information is received by decision-makers "," However, it is obvious that, instead of informing and explaining their own actions, public discussion about current problems, the authorities chose a strategy dissociation from criticism and suppression of socially important information, turning the media into a typically entertaining product." At the same time, experts believed that such an approach by the authorities can have only a shortterm effect. In the future, such a government policy may cause a decrease in public confidence in traditional media, a decrease in their ratings, the outflow of a significant part of the audience to the Internet, the transformation of online publications and social networks into the main source of information and the gradual withering away of journalism as a profession" ${ }^{10}$.

January 16, 2014 The Verkhovna Rada adopted, and on January 17, V. Yanukovych signed a series of laws that the democratic public immediately called dictatorial. And the opposition even called it a "coup d'etat." The adopted laws have substantially fueled the "Maidan mood". The claims of the public and the opposition were justified, since the purpose of the laws, among other things, was to significantly limit civil rights to freedom of speech and information. So, Law 721-Y11

\footnotetext{
${ }^{9}$ Freedom House: украинская пресса стала менее свободной Available at: http://www.pravda.com.ua/rus/news/2011/05/2/6157339/).

${ }^{10}$ Представители власти заполонили телевизор Available at: http://www.pravda.com.ua/ rus/news/2011/10/8/6648423/.
} 
"On Amending the Law" On the Judicial System and the Status of Judges " provided for criminal liability for defamation, extrajudicial blocking of sites that, according to experts, violated the law, control of mobile communications, in particular, purchase and service mobile phone cards only by passport on the basis of an agreement signed with the operator.

Naturally, the international community reacted to what was happening here, which doubted the usefulness of the adopted laws for Ukrainian democracy. Thus, the US Administration considered that this could weaken democracy, and the Council of Europe said that these laws violate the European Convention on Human Rights. The OSCE criticized the criminal defamation rule, believing that freedom of speech is thus at risk.

Under pressure from the Ukrainian and international public, on January 28, 2014, the Verkhovna Rada repealed most of the adopted laws.

However, during the cadet period of President Petro Poroshenko, many of the so-called "dictatorial laws" found a new, sometimes tougher sound. So already in August 2014, the law of Ukraine was adopted, which allowed the president and the National Security and Defense Council to block objectionable sites and TV channels. In 2017, according to the decree of the President of Ukraine P. Poroshenko, social networks VKontakte, Odnoklassniki and others were blocked. Representatives of the ruling parties "Petro Poroshenko Bloc" and "People's Front" several times initiated laws that criminalize libel and facilitate the closure of Internet resources.

Such a policy of the Ukrainian government has led Ukraine to take a place in the list of countries with "partial freedom" in the Freedom House rating of Freedom House - 2019 human rights organization. The organization reports that Ukraine scored 56 points out of 100. In 2018, Ukraine received 55 points. The rating evaluated such criteria: an obstacle to access by the authorities, censorship and violation of user rights. It includes 65 countries, which account for $87 \%$ of network users worldwide. The report analyzed the events from June 2018 to May 2019. When assessing the situation in Ukraine, the drafters of the rating negatively noted the blocking of Russian sites in February 2019, attempts by the authorities to adopt a law on the responsibility of the media for the "hostile language"; large-scale disinformation campaign that accompanied the presidential election, as well as the situation with the journalists of the Scheme and the Prosecutor General, who wanted to access their phones. Freedom House experts do not consider Russia's subversive propaganda against Ukraine as a compelling reason to infringe on the rights of language communities. So the decision of the Lviv Regional Council, 
which prohibits the public use of Russian-language "cultural products", including films and books, was criticized ${ }^{11}$.

At the same time, Freedom House experts express hope that the situation with media freedom in Ukraine will improve. They rightly point out that the media have the ability to criticize the authorities, and slander is not a criminal offense. However, everything can change with the adoption of the Disinformation Law, which will be discussed in the next paragraph.

\section{Freedom of speech and information under the President of Ukraine Vladimir Zelensky}

With the coming to power of President V. Zelensky, society expected liberalization of relations between state authorities and the media. However, today it is already obvious that the new government in many ways not only repeats the mistakes of the old government, but also in some way already admits them even more. So, for example, the Office of the President hastened to declare that it does not need the media at all to communicate with society. Also, the President's Office was spotted trolling the media by giving him fake information.

The Cabinet of Ministers of Ukraine closed its meetings for journalists and limited itself to a briefing. While at the time of A. Yatsenyuk and V. Groisman, the Cabinet meeting was broadcast live.

In parliament, proposals began to be heard on the selective accreditation of journalists, and a Temporary Investigation Commission was being created to investigate the activities of some media. On November 6, 2019, parliamentary hearings were held on the topic "Safety of the activities of journalists in Ukraine: state, problems and solutions”, at which the Minister of Culture proposed to formulate a legal definition of "information manipulation" and introduce its criminal liability for journalists. All this, in our opinion, casts doubt on the possibility of Ukrainian exercising its right to freedom of speech and information.

Numerous scandals undermine public confidence in both the government and the media. Thus, the openness and transparency of the activities of the authorities are replaced by the non-publicity of its relations with society, a hostile environment is created in relation to the media that criticize the authorities. Our European partners also declare pressure on the

11 Украина в рейтинге оказалась на одном уровне с Индией, Марокко, Малайзией и Угандой. Available at: https://tsn.ua/ru/ukrayina/freedom-house-ocenila-uroven-internetsvobody-v-ukraine-1437942.html. 
media in Ukraine. And this will undoubtedly affect the ranking of both the President and parliament.

It can be assumed that the authorities behave this way because of the bias of most of the media, which have never been and are today not the standard of democratic journalism, but rather a propaganda machine that works in the interests of its owners and specific political forces. However, this does not mean that the government should not engage in communication with the media and form an information agenda. After all, as you know, absolutely free and independent media do not exist. Some of them depend on the state, others on a business that pursues certain political and commercial goals, "which will lead to censorship and restriction in topics"12

On January 20, 2020, the Ministry of Culture, Youth and Sports of Ukraine presented to the public a bill on countering disinformation, according to which journalists and mass media distributing fake news and information using fake accounts and bots will be subject to administrative and criminal liability. The law defines false information as false information about individuals, events or events. According to the authors of the law, misinformation is unreliable data of public importance on national security, the territorial integrity of the country and the health of citizens. The law defines "mass media distributors", which recognize "individuals or legal entities that create, collect, or disseminate mass information." The bill provides for the introduction of a new post - the Commissioner for Information, whose duties will include monitoring the media in order to identify information that violates the law. Contact law enforcement and the court. Develop criteria for the so-called confidence index, which will be assigned to the media as they wish. The so-called "tools of influence" on the media are introduced - "The right to answer" and "The right to refute" 13 .

It is natural that this bill was sharply criticized by European journalists who saw in it the risks to freedom of speech and information in Ukraine ${ }^{14}$.

12 Международная федерация журналистов включила Украину в число 5 стран с высоким уровнем опасности для работы журналистов. Українські новини. Available at: https://ukranews.com/news/663967-dlya-zhurnalistov-kiev-samyj-opasny

${ }^{13}$ Штрафы за фейки. У Бородянского представили законопроект о дезинформации Available at: https://nv.ua/biz/markets/v-minkulte-predstavili-zakonoproekt-o-dezinformaciinovosti-ukrainy-50065133.html.

${ }^{14}$ Европейские журналисты раскритиковали закон Бородянского о фейках. Available at: https://www.depo.ua/rus/politics/evropeyski-zhurnalisti-rozkritikuvali-ukrainskiyzakon-pro-feyki-202001221100010. 
The arguments of the initiators of the bill that it was created to combat Russian propaganda during the period of Russian aggression did not convince Europeans. Moreover, they believe that unwanted Ukrainian journalists and the media will be prosecuted with the help of the law. EFJ General Secretary Ricardo Gutierrez spoke clearly about this: "The government must strictly adhere to journalistic self-regulation and independence. The state must create the conditions for this process, avoiding any government interference and not deprive journalists of their rights. EFJ categorically rejects any proposal that the state will to regulate journalistic activities and impose any restrictions on journalists, "said EFJ Secretary General Ricardo Gutierrez.

Many countries of the world are now actively developing and applying a set of measures to protect their society from "information intervention", carried out, as is known, by the "monopolists" in this area - the USA, China, Japan, and European countries. Modern states consider superiority in the information sphere as one of the important factors for achieving the goals of their national strategy. This is evidenced by the attention given to the creation of specialized units in the structures of the armed forces and special services, the development of conceptual documents governing the preparation and conduct of information operations.

In Germany, a law was passed in 2017, according to which social networks with more than 2 million users are required to remove inaccurate information aimed at inciting hatred. This is given one day or the right to file a complaint within a week. For failure to comply with the law, owners of Internet resources will be fined.

French President Emmanuel Macron called untruthful information a threat to liberal democracies, which must be fought. To this end, he will initiate changes in French law. "If we want to protect liberal democracies, we must have strong legislation," Macron said in a New Year's address to reporters. According to the French president, changes in legislation should also affect social networks, especially their use in election campaigns ${ }^{15}$. So in 2018, two laws were passed in France that prohibit the dissemination of "inaccurate or false allegations and allegations that aim to change the true results of voting" three months before the election. A politician or party may go to court during this period and demand that they stop publishing such information.

15 Макрон инициирует закон по борьбе с «фейковыми новостями». Available at: https://www.rbc.ua/rus/news/makron-initsiiruet-zakon-borbe-feykovymi-1515020950.html. 
Social networks in France can publish commercial political advertising, but they must disclose the customer and indicate the amount earned. The French High Council on Audiovisual Media will have the right to block broadcasting of a "foreign television channel or channel under the influence of a foreign state" in the country if it deliberately misinforms.

In Italy, they found their own approach to the fight against news misinformation. Using a special service, Italian citizens can report to the police about "fake", in their opinion, news. After such a statement, news on "fake" will be checked by special police experts. The results of the verification will be published in official appeals to citizens. If the news turns out to be untrue, the media will have to refute them. So far, this applies to electronic media and Internet resources. According to the police, this service does not interfere with freedom of speech in Italy. "We are not trying to create a Big Brother," assured Italian police chief Franco Gabrielli $^{16}$.

Also in 2018, a law against fake news was adopted in Malaysia. Here it is forbidden not only to spread a lie, but also to repost it. Criminal liability is also provided.

After the victory of the opposition in the elections in May 2018, the new leadership of the country is trying to revise the law, but it is resisting in parliament.

The experience of Singapore is also interesting, where in 2018 a special commission was created that studied the effect of fake news on the state. According to experts, the country is "the goal of hostile information companies that can undermine the country's social unity." Singapore has yet to develop a law against fake news.

Criminal liability for disseminating fake news is legally provided for in Kenya. A law passed in 2018 considers spreading fake news a crime. They face a fine or a prison term of up to 2 years.

There is also criminal liability for misinformation in Qatar. The 2014 law provides for a fine or a three-year prison term.

In Egypt, in 2018, two laws were adopted to combat fake news. Here, the government gained the right to restrict access to sites that threaten national security. Blogs with 5 thousand subscribers are equated with the media. They are allowed to block out of court.

16 «Не хотим Большого Брата»: в Италии о фейках в новостях теперь извещают полицию. Available at: https://vesti-ukr.com/mir/274057-ne-khotim-bolshoho-brata-v-italiio-fejkakh-v-novostjakh-teper-izveshchajut-politsiju. 
As we see in European democracies, there is no criminal liability for misinformation. In our opinion, Ukraine should do the same, having made a European choice.

The Minister of Culture, Youth and Sports, Vladimir Borodyansky, the initiator of the law on combating disinformation, noted that in preparing the law, the experience of Great Britain, France and other countries of the European Union was studied. "But we have to understand one thing that Ukraine, which today faces such challenges, is obliged to create its own legislation in this area. And not just create our own, I think that this legislation will become part of European legislation when we do all this here ... I believe that information attacks continue, threats persist, and our responsibility is to ensure that Ukrainians reduce the consumption of misinformation, "said V. Borodyansky ${ }^{17}$.

\section{CONCLUSIONS}

So, the objectively growing globalization of the information sphere leads to the fact that the created information and communication infrastructure of the country and national information resources turn out to be objects very vulnerable to influence from geopolitical competitors, terrorist organizations, criminal groups and individual attackers. Given these factors, the information development of Ukraine, which is noticeably behind the leading industrialized countries, should be carried out as part of a systematic and balanced state information policy aimed at actively combating information aggression.

However, if the new government is genuinely committed to the development of a democratic state and society, it must establish effective and full-fledged interaction with the media in accordance with democratic values.

State officials should understand that in the information society (in particular, the intensive development of social networks that they themselves are actively using today), the unilateral manipulative influence of the state on public consciousness in order to control the main Ukrainian information resources is no longer possible.

Ukrainian society urgently needs to establish at the legislative level clear relations between the media and their owners in order to reduce the

17 Бородянский: только 8\% украинцев могут отличить фейк от не фейка. Available at: https://www.unian.net/society/10767131-borodyanskiy-tolko-8-ukraincev-mogut-otlichitfeyk-ot-ne-feyka.html. 
dependence of the former on the latter. Only in this way can the media be reflected not in the interests of the owners, but in society.

Changing the political consciousness, value orientations, political culture of the population and achieving mass support for the declared political, social and economic reforms is possible only through the media. The sooner the new Ukrainian government realizes this, the better. 


\section{SUMMARY}

The article discusses the problems of communication between the authorities and the media in modern Ukraine. A comparative analysis of the degree of freedom of the information space under V. Yanukovych, P. Poroshenko and V. Zelensky. The essence of media processes in Ukraine is considered. It is shown that the role of the media is due to their ability to shape the media agenda in political discourse and influence decision-making mechanisms. Foreign experience in combating false information is considered.

\section{REFERENCES}

1. Бородянский: только $8 \%$ украинцев могут отличить фейк от не фейка. Available at: https:/www.unian.net/society/10767131borodyanskiy-tolko-8-ukraincev-mogut-otlichit-feyk-ot-ne-feyka.html.

2. Брайант, Дж. (2004). Основы медиа-воздействия. М., 2004, 432 с. С. 157.

3. Европейские журналисты раскритиковали закон Бородянского o фейках. Available at: https://www.depo.ua/rus/politics/evropeyskizhurnalisti-rozkritikuvali-ukrainskiy-zakon-pro-feyki-202001221100010.

4. Золотникова М.С. Роль средств массовой информации в формировании идеологиии культурных ценностей общества. Available at: http://elar.rsvpu.ru/bitstream/123456789/6882/1/it_mho_ 2008_3_006.pdf).

5. Макрон инициирует закон по борьбе с «фейковыми новостями». Available at: https://www.rbc.ua/rus/news/makron-initsiiruetzakon-borbe-feykovymi-1515020950.html

6. Международная федерация журналистов включила Украину в число 5 стран с высоким уровнем опасности для работы журналистов. Українські новини. Available at https://ukranews.com/news/663967-dlyazhurnalistov-kiev-samyj-opasny.

7. Милиция перечитает страницы пользователей «ВКонтакте» Available at: http://podrobnosti.ua/internet/2010/07/07/698868.html.

8. «Не хотим Большого Брата»: в Италии о фейках в новостях теперь извещают полицию. Available at: https://vesti-ukr.com/mir/ 274057-ne-khotim-bolshoho-brata-v-italii-o-fejkakh-v-novostjakh-teperizveshchajut-politsiju.

9. По данным социологического опроса КМИС, центральным телеканалам доверяют $40 \%$ опрошенных украинцев Available at: https://news.liga.net/society/news/komu-iz-smi-bolshe-vsego-doveryayutukraintsy---opros. 
10. Представители власти заполонили телевизор Available at: http://www.pravda.com.ua/rus/news/2011/10/8/6648423.

11. Самошкин, Е.А. (2017). Институты борьбы с дезинформацией и мисинформацией в СМИ. Вестн. Моск. ун-та. Сер.10. Журналистика. № 6. С. 176-190.

12. Украина в рейтинге оказалась на одном уровне с Индией, Марокко, Малайзией и Угандой. Available at: https://tsn.ua/ru/ukrayina/ freedom-house-ocenila-uroven-internet-svobody-v-ukraine-1437942.html.

13. Украина опустилась в рейтинге свободы слова. https://tsn.ua/ru/ukrayina/ukraina-opustilas-v-reytinge-svobody-slova1331460.html. Available from https://tsn.ua/ru/ukrayina/ukraina-opustilasv-reytinge-svobody-slova-1331460.html.

14. Штрафы за фейки. У Бородянского представили законопроект о дезинформации Available at: https://nv.ua/biz/markets/v-minkultepredstavili-zakonoproekt-o-dezinformacii-novosti-ukrainy-50065133.html.

15. Freedom House: украинская пресса стала менее свободной Available at: http://www.pravda.com.ua/rus/news/2011/05/2/6157339/.

16. Luhmann, N. (1996). Die Realitat der Massenmedien. Opladen: Westdeutscher Verlag, 223 p.

17. Oxford living dictionaries. Definition of disinformation in English. Available at: https://en.oxforddictionaries.com/definition/ disinformation.

Information about the authors: Silenko A. A., Doctor of Political Sciences, Professor, Vice-Rector, Odessa National Academy communication of A. S. Popov 1, Cuznechna str., Odessa, 65000, Ukraine

Kormych A. I., PhD in History, Associate Professor, Associate Professor at the Department of General Jurisprudence, National University «Odessa Law Academy» 2, Akademichna str., Odessa, 65009, Ukraine 